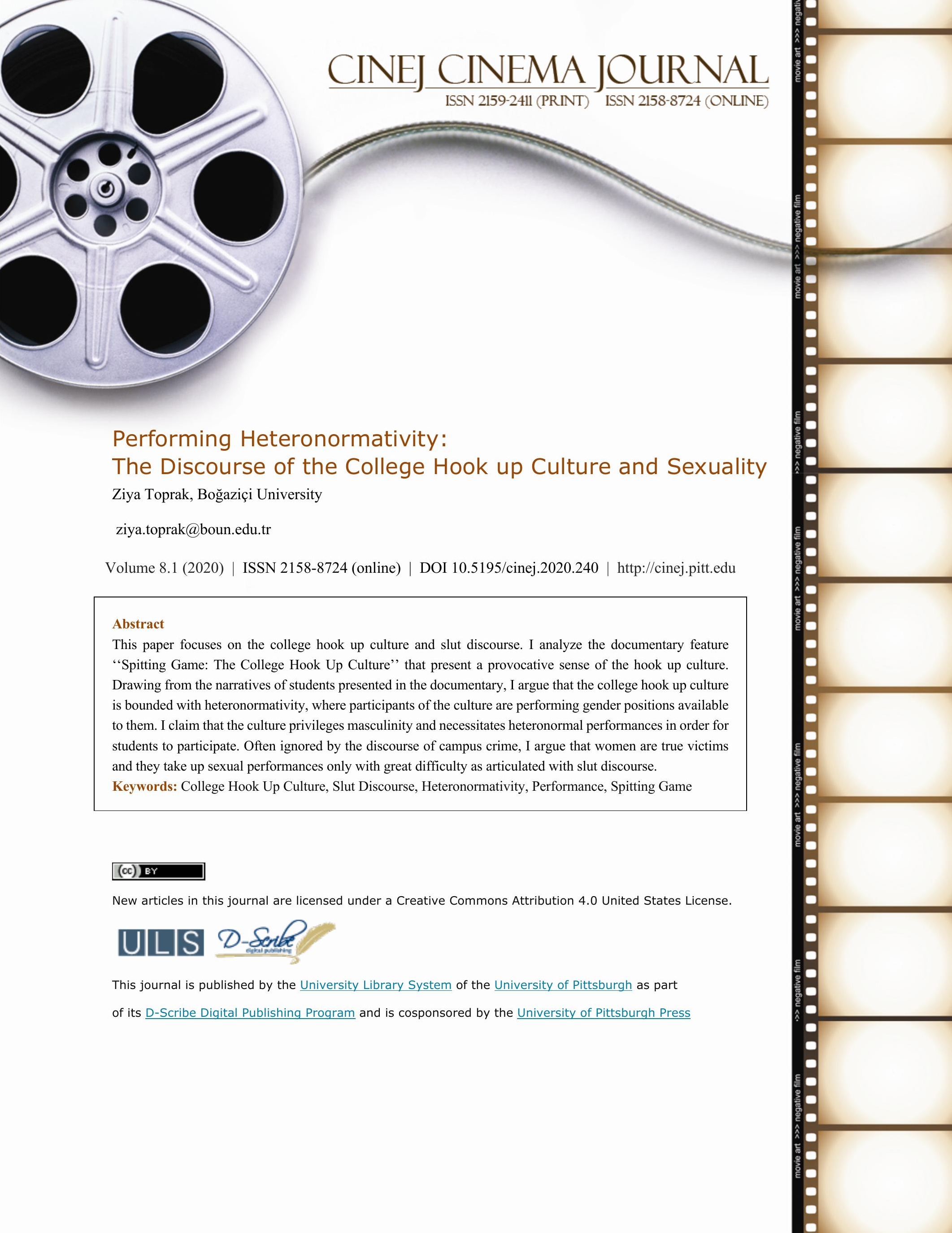




\section{Performing Heteronormativity: The Discourse of the College Hook up Culture and Sexuality \\ Ziya Toprak}

\section{Introduction}

Hook up is a common North American notion describing sexual encounter with no strings attached among adolescents (Manning, Longmore \& Giordano, 2005; Paik, 2010) and adults (Olmstead, Billen, Conrad, Pasley \& Fincham, 2013; Olmstead, Pasley \& Fincham, 2013)1. Mostly defined as a form of physical intimacy, hook up does not necessarily mean intercourse (Paul and Hayes, 2002), yet it does not involve commitment (Heldman and Wade, 2010) and long-term expectation (Fielder, Carey and Carey, 2013). The documentary "Spitting Game: The College Hookup Culture" is visual invite to witness the first-person narratives this hook up culture encounters.

The documentary is an interesting text to read in the sense that it offers a critique to the hookup culture and criminalizes campuses in a different way than the dominant discourse of campus crime where sexual assault and rape are mostly silenced. The notion of campus crime is relatively a new discourse, which has been socially constructed since the late 1980 s, despite the fact that campus crime has existed on campuses since they were first founded. Accordingly, campus crime refers to various forms of violence, vice and victimization involving students as offenders and victims. 
Campus crime has been gradually constructed as a social problem through various processes involving claims makers definition of the problem, legitimization of problem, packing it ideologically and producing consequences (Bopp and Wittman, 2011; Lewis, Farris, and Green, 1997; Sloan, 1992; Baum and Klaus, 2005; McConnell, 1997). Interestingly, sexual violence, assault or rape does not appear as a serious crime within the discourse. To put in a more scrutinized way, the campus crime discourse does not oversee the sexual crimes, but it opts to see them as a criminal activity only, where I claim that sexual crimes are very products of the gendered space of college and the discourse of campus crime. I argue that the documentary is making a good job in showing us what the campus crime discourse often ignores, which is the hook up culture and its violent consequences. In this paper, I will discuss these consequences in relation to heteronormativity and masculinity of the college hookup culture.

Discourse, since Foucault, is not merely a set of statements dictating terms of speech but also a strategic dimension that provides the rhetorical and material background for the truth defining and forming power relations between institutions, groups and individuals. The distinctive point in Foucauldian approach to discourse is that it does not take an interest in the meaning and hidden motivations of a particular discourse, but it specifies on the ontological and epistemological conditions that makes the discourse possible. Therefore, the key stance in the approach is to 
analyze discourse's material effects because in the end discourses are the products of activities and performances done within a complex structure of knowledge and power. The discourse of sexuality has been long a field of academic inquiry leaded by feminist scholars. Generally speaking, the feminist scholars examine the issue of gender under three different captions, i.e. the first wave feminism (liberal-humanistic), second wave feminism (socialist) and post-structural feminism. Each of these movements has their distinctive theoretical articulations and history. In this paper, I will first briefly articulate these movements in order to provide a conceptual framework for an analysis the college hookup culture described in the documentary. Then I develop a critique of the college hookup culture to describe heteronormal and sexist culture of college life in the US.

\section{Feminism, Sexuality and Fluid Identities}

The first-wave feminism was a response to biological essentialism and refers to the feminist movement in the nineteenth century and early twentieth century, which primarily focused on gaining the right of women's suffrage. The first wave was much more connected to liberal thinking which was mainly individualistic and based on the dominance of rationalism and Cartesian being. In this essentially reasoned being, women were just like men, leaving the challenge the idea of male and maleness as normative aside. The first wave is much more evaluated within context of liberal-humanistic thought so that it can be called as liberal feminist ideology, which is "implicated in the replacement of collective consciousness about race/gender/ability stratification with 
individualized strategies for getting ahead" (Mojab and Gorman, 2003, 233). The idea is to decline in collectivity and to find individual solutions to collective problems. The woman is constructed as a locus to be empowered, which has always become a central concern with the rise of liberal ideology. The woman needs to be empowered to increase her own capacity of shaping her life. The problem with the discourse of empowerment is portrayed as highly technical hence concealing the political nature of the problems and structural constraints within which woman faces. Within the discourse of empowerment, woman is not a special category but is allied with the category of poor and the problematic of gender is articulated through the discourse of development, which takes a different form in the second wave feminism.

Second wave feminism is grounded in the socialism and radical critiques of it. It is a wellknown idea that gender issue is not well articulated among within the conceptual framework of Marxism. . Socialist feminists, while using the Marxist method and framework, do not subsume all forms of oppression under economics (Weedon, 1997). Materialist feminism is not biologically essentialist yet can still be considered essentialist since it creates a universal category called "woman" and claims that this category is oppressed historically, across locations and cultures. However, the materialist feminists do not claim intrinsic attributes for the category of "woman;" instead, it claims that women as individuals and groups are shaped by the material forces in their 
lives (Weedon, 1997; Hennessy, 1993). Within the context of second wave feminism woman is an object to be emancipated through consciousness-raising so that she can achieve her subjectivity. The process of consciousness-raising is a collective and group-defined. "Group consciousness, whether it crystallizes around ideas of class, gender, race, nationality, ability, or sexuality, is always a dynamic, dialectic phenomenon. Group consciousness is not a static or passive set of ideas, but a process or movement” (Mojab and Gorman, 2003, 237). Consciousness-raising, which is considered to originated from collective debate, community problem solving, and solidarity, is a critical theme within the framework and a source of theoretical problem, which well echoed and criticized by post-structural feminists.

During the second wave a strong critique aroused claiming that feminism was a notion representing only white, middle-class, heterosexual Western women and then claiming to represent "women" as a whole - an essentialist, universalizing viewpoint not dissimilar to the maledominated traditions that these early feminists critiqued (Nicholson, 1990). Those who critiqued these early works and have helped open up different avenues for feminism included many groups such as third world feminists, post-colonialist feminists, lesbians, and feminists not of the racial majority in a country, such as African American and Latina feminists in the United States. This movement, which can be called as post-structuralist feminism is very significant as a theoretical framework for variety of reasons. First, gender, power, language, discourse, knowledge and truth 
issues are central to this framework. Second, the purpose of examining the intersection of gender, race, class, sexual orientation, and religious orientation helps to understand the experiences of women's lives. Third, feminist post-structuralism actively challenges the existing patriarchal structures and discourses and conditions that make these structures possible to exist and endure.

Embracing the post-structuralist notion of plurality and that meanings are never static, poststructuralist feminism analyzes the relationship between language, social institutions and individual consciousness and how these factors interrelate with power and impact the potential for change (Weedon, 1997). Rejecting the essentialist positions totally, these feminists primarily concerned woman as category i.e. whether there was a meaningful category so called woman. Instead, they questioned categories like gender that seemed to be natural and were treated as a pregiven (Riley, 1988; Yücel, 2014). They claimed that gender was a discursive production, continually constructed by its expression (performance) in daily life (Butler, 1989). The account of post-structuralism advanced "a new understanding of gender as a routine accomplishment embedded in everyday interaction" (West \& Zimmerman, 1987, p. 125).

Seeing gender as a performance, constantly claimed through action in daily life is a relatively new idea. West and Zimmerman (1987) are among the firsts to develop this theoretical contribution. They see gender as something we do. They propose an "understanding of gender as 
a routine, methodical, and recurring accomplishment" which is "undertaken by women and men" (p. 126). While gender is something that individuals do, they are not completely free in doing it, since limits of actions and reactions are culturally and socially situated. In this sense, gender is a product of social doing; a process that constantly draw distinctions between girls and boys, and women and men. Thus these distinctions or "the sociocultural shaping of essential female and male natures, achieve the status of objective facts. They are rendered normal, natural features of persons and provide the tacit rationale for differing fates of women and men within the social order" (p. 142). Seeing gender in a similar vein Butler (1993) advances a more radical contribution to gender studies.

The account of Butler is more radical in the sense that she challenges the very notion of identity, being someone or something. By destabilizing the categories of gender and sexual identity, Butler offers more fluid account of identity. She basically sees the category of identity as an "instrument of regulatory regimes" (Butler, p. 308). Accordingly to be someone or something implies a fixed ontological category, that leaves others automatically out; an understanding she firmly opposes and has troubles with. For example, she is very skeptical about the category of lesbian for its significations. She considers such categories "to be invariable stumbling-blocks" and promotes them "as sites of necessary trouble" (p. 308). The word trouble has significant meanings in Butler's framework and deserves special attention. Trouble literally means something 
that one should never do, because its consequences might not be pleasant. Trouble, for Butler, is task to reveal "the gender categories that support gender hierarchy and compulsory sexuality" (Butler, 1989, p. viii). The primary concern for Butler is to answer the question of "what happens to the subject and to stability of gender categories when epistemic regime of presumptive heterosexuality is unmasked as that which produces and reifies these ostensible categories of ontology" (p, viii). Following Foucault's genealogy, Butler, instead of seeking essences that make up the gender categories, seeks to decenter gender categories and compulsory heterosexuality by shaking their discursive foundations. In this sense, she troubles gender. So what happens if gender is troubled?

Butler argues that gender is a kind of imitation that has no original. It has no interior truth but "the repeated stylization of the body...that congeal over time to produce the appearance of substance, of a natural sort of being" (p. 33). It is constantly imitated; a kind of imitation that produces the very notion of the original as effect and consequence of the imitation itself. In this sense, gender is always performed as an imitation that sets itself as the origin if all imitations (Butler, 1993). The key here is there is not original that imitation imitates. In this sense, heterosexuality is an imitation of imitation; carbon copy where there is no origin. 
Slut Discourse, Hookup Culture and Heteronormativity in College Campuses

Spitting Game: The College Hook Up Culture is an intimate look into campus lives of college students. 82-minute feature film depicts the transition from "traditional dating pattern" to hooking up, described as drunken, no strings attached sexual relationships. Director, Denice Ann Evans, examines challenges, risks, and realities students come across within the culture by leading the audience on issues like alcohol and drug abuse, hooking up, peer pressure, sexual assault and consent. While the discourse of campus crime most of the time opts to ignore the sexual crime taking on college campuses, the documentary provocatively focuses the campus as a gendered space and raises serious questions about sexuality, gender, and sexual assault on campuses. Drawing from narratives of students, parents, and psychologists, Evans unearths the darks side of the hook up culture, where stories of sexual assault and rape are abundant.

The hook up in the documentary is defined commonly as anything kissing and beyond while no strings attached. One of the participant of the documentary states it as "I mean, when I think of hooking up, I think of someone, like, you go to a party and you meet someone and you go home with him, and then you have sex, and then you may or may not talk to them ever again." This culture of relation is now a widespread pattern in most of the colleges. Obviously, the culture of hook up does not empower women in any way. Which is why we see confessions of next 
morning regrets. Especially if the hook up is mixed up with being drunk, in most cases the result is sexual violence or rape. Even if the result is not rape or sexual violence, as females in the documentary notes, girls attach more and are affected emotionally.

Moreover, as the documentary illustrates the hook up culture is an articulation and a mechanism of reproduction of heteronormativity and masculinity. Given that most of the rape and sexual incidents are happening in frat houses, and most of the times frat boys get away with it. Stories like "From there, he picked me up, and I was about 100 pounds, so I had no way of defending myself. He picked me up and was holding my legs and still kissing me, despite my screaming and movement, nothing happened" are common in frat houses. Because of the heteronormal and patriarchal culture, women "never actually wanted to talk about it afterwards, and they never reported it. So these guys literally got away with it, because these women didn't want to have that reputation. You know, nobody wants anybody to know that they've been raped." As the doctor in the documentary indicates, there is a lot of sexual violence incidents on campuses majority of which are not reported because of the fear of bad reputation.

Another point about the hook up culture is that it is constructed as heteronormal. Especially it is considered as a matter of heterosexuality. The documentary, since it articulates this culture as matter of boys and girls contributes the reproduction of heteronormativity. It feels like only boys 
and girls or more precisely only heterosexuals hook up, when you watch the film. The documentary provides perspectives heterosexual boys and girls. How they hook up, have sex, and feel afterwards are concerns of the documentary. "She wants to get to know this guy", "Can a man or woman make a conscious decision if they're drunk?'," A girl agreeing to kiss a guy" are just some examples of heterosexual statements. There are tons of this kind of statements telling us that sex is something happening between woman and man. By monopolizing the hook up culture as matter of heterosexuals, the documentary renders homosexuality to invisibility, as if it does not exist. I am not claiming that there is a homosexual hook up culture in campuses. I am just saying we do not see whether such a thing exists or not.

My last note is about the discourse of slut that appears several times in the documentary. In the beginning of the chapter 8- Fraternities, we hear a man saying, "Well, this girl, she's kind of known to be a slut. She'll definitely sleep with you. This girl's kind of prudish. If you can get her to hook up, you're the man." Or in the beginning of the chapter, a woman states, "If some of your girlfriends are going out and they're hooking up with other people, they don't want to feel like 'the slut' or 'the whore." Slut is then is discourse that draws a distinction among the women. The slut discourse denotes that a woman has had much sex, she has transgressed the moral code. Women are vulnerable to slut stigma when they violate the sexual standard and consequently experience status loss and discrimination. The slut label is one that women constantly have to avoid. "There's 
a special name for sleeping with five guys. That's pretty slutty. I think sluts can't even count the guys they've slept with" states a female in the documentary. When a woman sleeps with five guys, she becomes a slut. On the other hand if a man sleeps with five women, he is a hero or a champ, or at least it is something to brag about. The slut discourse shows us how the hook up culture is gendered and heteronormal thus disempowering women.

\section{Conclusion}

The documentary, Spitting Game: The College Hook Up Culture, depicts us the gender performances of students in a strictly gendered, heterosexual space, where mostly women exist as objects of sexual desire (Kalish, p. 162) "For many of the young men, young women are vessels in which they find pleasure, or, as we see here, women are vehicles which men use in the pursuit of status, which is something college men appear to think about and act on in meaningful ways" (Kalish, p. 162). The college hook up culture works in a way, as depicted, that privileges masculinity and heterosexuality upon which students are forced to perform their gender.

The stories of students unfolded in the documentary like any story make moral claims (Benjamin, 1968). They explain why students, especially female students, constantly make references to slut discourse to draw a distinction so that they can occupy a morally valid space. The moral claim of the documentary is that we need to find new languages to talk about the gender 
trouble (Butler, 1989), in which gender is not understood in terms of affirmative and essential qualities that heteronormativity multiplies, but in terms of trouble: because of the dominance of societal norms, people perform gender positions available to them, only with great difficulty.

\section{BIBLIOGRAPHY}

Benjamin, W. (1968). Illuminations. Edited by Hannah Arendt. New York: Shocken Books Inc.

Baum, K. and Klaus, P. (2005). Violent Victimization of College Students, 1995-2002.

Washington, DC: US Department of Justice, Office of Justice Programs, Bureau of Justice

Statistics, (NCJ 206836).

Bopp M, Kaczynski A, Wittman P (2011). Active commuting patterns at a large, Midwestern

college campus. J Am Coll Health 59(7):605-611.

Butler, J. (1989). Gender trouble: Feminism and the subversion of identity. New York:

Routledge.

Butler, J. (1993). Imitation and Gender Insubordination. In Henry Abelove, Michele Aina Barale and David Halperin (Eds.), The Lesbian and Gay Studies Reader, (pp: 307-320). London:

Routledge. 
Fielder, R.L., Carey, K.B., \& Carey, M.P. (2013). Are hookups replacing romantic relationships?

A longitudinal study of first year female college students. Journal of Adolescent Health

(Adolescent Health Brief), 52(5), 657-659.

Heldman, C., \& Wade, L. (2010). Hook-up culture: Setting a new research agenda. Sex Research and Social Policy, 7(4), 323-333.

Kalish, R. (2013). Masculinities and hooking up: Sexual decision-making at college. Culture, Society and Masculinities, 5(2), 147-165.

Lewis L, Farris E, Green B (1997) Campus crime and security at postsecondary education institutions. US Department of Education, Office of Educational Research and Improvement, National Center for Education Statistics, New York.

Manning, W. D., Longmore, M. A., \& Giordano, P. C. (2005). Adolescents' involvement in nonromantic sexual activity. Social Science Research, 34(2), 384-407.

McConnell, E. H. (1997). Fear of crime on campus: A study of a southern university. Journal of Security Administration, 20(2), 22-46.

Mojab, S., \& Gorman, R. (2003). Women and consciousness in the "learning organization": Emancipation or exploitation?. Adult Education Quarterly, 53(4), 228-241.

Nicholson, L. (Ed.). (1990). Feminism/Postmodernism. New York: Routledge. 
Olmstead, S. B., Billen, R. M., Conrad, K. A., Pasley, K., \& Fincham, F. D. (2013). Sex, commitment, and casual sex relationships among college men: A mixed-methods analysis. Archives of Sexual Behavior, 42(4), 561-571.

Olmstead, S. B., Pasley, K., \& Fincham, F. D. (2013). Hooking up and penetrative hookups:

Correlates that differentiate college men. Archives of Sexual Behavior, 42(4), 573-583.

Paik, A. (2010). The contexts of sexual involvement and concurrent sexual partnerships.

Perspectives of Sexual and Reproductive Health, 42(1), 33-42.

Paul, E.L., \& Hayes, K.A. (2002). The casualties of 'casual' sex: A qualitative exploration of the phenomenology of college students' hookups. Journal of Social and Personal Relationships, 19(5), 639-661.

Renner, K. J. (2016). Monstrous schoolgirls: Casual sex in the twenty-first-century horror film.

Red Feather Journal, 7(1), 31-49.

Riley, D. (1988). Am I that name?:Feminism and the category of 'women' in history.

Minneapolis: University of Minnesota Press.

Sikand, N. (2015). Filmed ethnography or ethnographic film? Voice and positionality in ethnographic, documentary, and feminist film. Journal of Film and Video, 67(3-4), 42-56.

Sloan, J. J. (1992). The modern campus police: An analysis of their evolution, structure, and function. American Journal of Police, 11(2), 85-104. 
Wade, L. (2017). American hookup: The new culture of sex on campus. WW Norton \&

Company.

West, C., \& Zimmerman, D. H. (1987). Doing gender. Gender \& society, 1(2), 125-151.

Weedon, C. (1997). Feminist practice and poststructuralist theory (2nd ed.). Cambridge, MA:

Blackwell Publishers.

Yücel, B. V. (2014). Kahramanın Yolculuğu. İstanbul: Bilgi Üniversitesi Yayınları.

\section{ENDNOTES}

\footnotetext{
${ }^{1}$ Hook up culture in colleges are covered in comedy films (Animal House, American Pie, Easy A etc) as well as slasher horror films (Friday the 13th franchise) and analysed in gender studies previously (see Renner 2016; Wade 2017). There is a lack of study on the subject in film studies which CINEJ aims to fulfil though this article. [Editor's Note].
} 